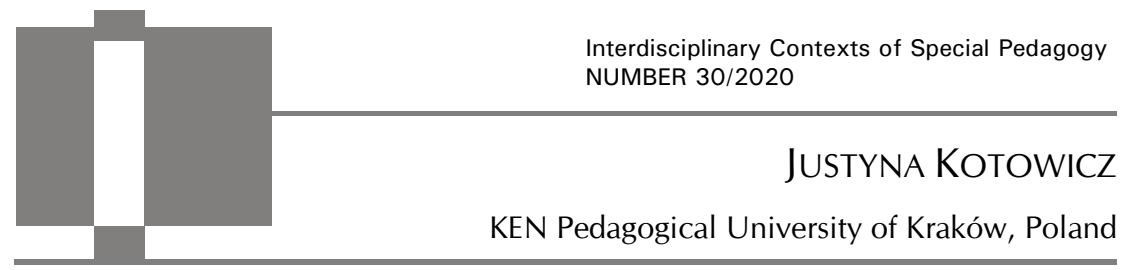

\title{
Reading skills of D/deaf students - native signers
}

\author{
AbSTRACT: Justyna Kotowicz, Reading skills of D/deaf students - native signers. Inter- \\ disciplinary Contexts of Special Pedagogy, no. 30, Poznań 2020. Pp. 151-167. Adam \\ Mickiewicz University Press. ISSN 2300-391X. e-ISSN 2658-283X. DOI: https://doi. \\ org/10.14746/ikps.2020.30.08
}

Reading skills of D/deaf students fall behind their hearing peers. The difference in reading skills between $\mathrm{D} /$ deaf and hearing children has not decreased for over past three decades. Low level of reading skills in D/deaf students has been associated with their language delay, which is mainly observed in D/deaf children using spoken language that is not fully accessible to "D/deaf individuals" instead of "ppl with hearing impairment". D/deaf children immersed in sign language since their birth usually do not encounter language problems and they have a potential to become highly-skilled readers. In the present studies we have investigated reading skills of D/deaf students who are native signers of Polish Sign Language. The results have indicated that D/deaf students showed lower level of reading skills than their hearing peers. The present studies call in question Polish education system dedicated to D/deaf students who are native signers. The obtained results suggest that reading classes are probably not adapted to the needs and abilities of highly competent signers.

KEY WORDS: D/deaf students, reading, Polish Sign Language 


\section{Introduction}

The existing studies indicate that D/deaf students ${ }^{1}$ show lower level of reading skills than their hearing peers. ${ }^{2}$ These results have been constant for many decades ${ }^{3}$ and the improvement in this educational area has been one of the greatest challenges faced by "deaf education" instead of "deaf educators". Learning to read is a particularly demanding task for D/deaf students due to the fact that they do not have the same access to spoken language by hearing and speaking as their hearing peers. ${ }^{4} \mathrm{D} /$ deaf children (DC) many a time learn spoken and written language simultaneously and often they learn to read without good language skills and with limited ability of mapping between the language and the written words. ${ }^{5}$ Meta-analysis of the currently available studies ${ }^{6}$ indicates that language competences are of significant importance for reading abilities of D/deaf students,

1 The paper uses D/deaf capitalization allowing for usage of both upper and lower case. The term "Deaf" (upper case) refers to linguo-cultural minority (cultural paradigm), whereas lower case letter refers to medical hearing loss perceived as deficiency (medical paradigm). It appears that the every? D/deaf persons should decide which term describes them and not the authors of scientific texts and papers. Thus, this paper uses capitalization which enables D/deaf persons to choose the preferred version and which shows the subject-approach to D/deaf persons.

2 S.D. Antia, P.B. Jones, S. Reed, K.H. Kreimeyer, Academic status and progress of deaf and hard-of-hearing students in general education classrooms, "Journal of Deaf Studies and Deaf Education", 2009, 14(3), pp. 293-311; C.B. Traxler, C.B, The Stanford Achievement Test, 9th Edition: National Norming and Performance Standards for Deaf and Hard-of-Hearing Students, "Journal of Deaf Studies and Deaf Education", 2000, no. 5(4), pp. 337-348.

3 S. Qi, R.E. Mitchell, Large-scale academic achievement testing of deaf and hard-ofhearing students: Past, present, and future, "Journal of Deaf Studies and Deaf Education", 2012, no. 17(1), pp. 1-18.

${ }^{4}$ J. Kotowicz, Proces czytania głuchych, „Rocznik Komisji Nauk Pedagogicznych", Oddział Kraków, 2013, no. LXVI, pp. 173-184.

5 S. Goldin-Meadow, R.I. Mayberry, How Do Profoundly Deaf Children Learn to Read? "Learning Disabilities Research and Practice", 2001, no. 16(4), pp. 222-229.

${ }^{6}$ R.I. Mayberry, A.A. del Giudice, A. Lieberman, Reading achievement in relation to phonological coding and awareness: a meta-analysis, "Journal of Deaf Studies and Deaf Education", 2011, no. 16(2), pp. 164-188. 
irrespective of whether they refer to oral or sign language. The obtained results may appear surprising as sign language is different from oral language and writing. However, it should be noted that sign language allows for linguistic, emotional, social and cognitive development of D/deaf people.7,8 Sign language competences may constitute basis for reading skills of DC, which is confirmed by studies ${ }^{9}$ according to which the higher level of sign language competences shown by D/deaf students the better results they exhibit for reading.

It needs to be stressed that foreign scholars have performed a detailed analysis of various levels of sign language (phonological, semantic and syntactic) that may be of significance for reading skills. It has been indicated that in DC using Swedish Sign Language (Svenskt teckenspråk) reading ability correlates with phonologic competencies in a sign language. ${ }^{10}$ Moreover, Dutch studies have showed the relation between sign language vocabulary range and the level of reading skills in DC. American scholars have also observed that the knowledge of antonyms in American Sign Language, ASL, is a predictor of reading skills in D/deaf students. ${ }^{11}$

It appears crucial that the studies on correlation between sign language competences and reading skills do not concern only children but have significance in the in the lifespan of D/deaf individuals. The scholars noted that $\mathrm{D} /$ deaf adults show relation between the level of reading comprehension and the results of the American

7 P. Rutkowski, P. Mostowski, Polski język migowy narzędziem przeciwdziałania wykluczeniu, „Trendy. Internetowe Czasopismo Edukacyjne”, 2017, no. 1, pp. 18-22.

8 J. Kotowicz, Nabywanie jezyka migowego - dyskusja stanowisk, "General and Professional Education", 2015, no. 1, pp. 26-36.

${ }_{9}$ M. Strong, P.M. Prinz, A Study of the Relationship Between American Sign Language and English Literacy. "Journal of Deaf Studies and Deaf Education", 1997, no. 2(1), pp. 37-46.

${ }^{10}$ E. Holmer, M. Heimann, M. Rudner, Evidence of an association between sign language phonological awareness and word reading in deaf and hard-of-hearing children. "Research in Developmental Disabilities", 2016, no. 8, pp. 145-159.

${ }^{11}$ R. Novogrodsky, C. Caldwell-Harris, S. Fish, R.J. Hoffmeister, The Development of Antonym Knowledge in American Sign Language (ASL) and Its Relationship to Reading Comprehension in English. "Language Learning", 2014, no. 64(4), pp. 749-770. 
Sign Language Sentence Reproduction Test, ASL-SRT, which evaluates, among the others, grammar, phonological and lexical competences. ${ }^{12}$ The same studies revealed that D/deaf adults of high sign language competences exhibited higher bilingual competences, including higher level of reading comprehension. ${ }^{13}$ It has also been observed that $\mathrm{D} /$ deaf persons of higher level of reading skills exhibited higher sign language syntactic skills and narrative comprehension. ${ }^{14}$

In the light of the presented studies it appears significant to stress that only a small number of DC has access to sign language since their birth. Approximately $10 \%$ of DC are born to families where parents are also D/deaf and most often are signers. ${ }^{15}$ The development of sign language in DC whose parents are deaf is similar to the development of spoken language that may be observed in hearing children (HC). DC who have D/deaf parents most often become native signers and do not show linguistic deficits that are often seen in DC brought up in hearing families. ${ }^{16} \mathrm{DC}$ who have D/deaf parents learn the world through a sign language, can develop their cognitive skills ${ }^{17}$, and what is more, $\mathrm{D} /$ deaf persons who have $\mathrm{D} /$ deaf parents achieve better results in reading skills than the ones who have hearing parents. ${ }^{18} \mathrm{DC}$ brought up by hearing parents often have problems communicating with hearing members of the family. ${ }^{19}$ Hearing par-

12 B.L. Freel, M.D. Clark, M.L. Anderson, G.L. Gilbert, M.M. Musyoka, P.C. Hauser, Deaf Individuals' Bilingual Abilities: American Sign Language Proficiency, Reading Skills, and Family Characteristics. "Psychology", 2011, no. 02(01), pp. 18-23.

13 Ibidem, pp. 18-23.

${ }^{14}$ C. Chamberlain, R.I. Mayberry, American Sign Language syntactic and narrative comprehension in skilled and less skilled readers: Bilingual and bimodal evidence for the linguistic basis of reading. "Applied Psycholinguistics", 2008, no. 29(3), pp. 367-388.

15 R.E. Mitchell, M.A. Karchmer, Chasing the Mythical Ten Percent: Parental Hearing Status of Deaf and Hard of Hearing Students in the United States. "Sign Language Studies", 2014, no. 4(2), pp. 138-163.

16 T. Humphries, P. Kushalnagar, G. Mathur, D.J. Napoli, C. Padden, C. Rathmann, Ensuring language acquisition for deaf children: What linguists can do. "Language", 2014, no. $90(2)$, pp. 31-35.

17 Ibidem, pp. 31-52.

18 M. Strong, P.M. Prinz, 1997, op. cit., pp. 37-46.

${ }^{19}$ A. Czyż, K. Plutecka, Zarys audiofonologii edukacyjnej. Wydawnictwo Naukowe Uniwersytetu Pedagogicznego, Kraków 2018. 
ents usually use a spoken language that may be not fully understood and incorrectly produced by DC. Additionally, limited communication may negatively affect cognitive development of DC, who do not have full access to linguistic information about the surrounding reality. As a result, DC brought up by hearing parents often have cognitive deficits and educational problems that to a lesser extent affect DC in D/deaf families. ${ }^{20}$ It is worth stressing that the group of $\mathrm{D} /$ deaf students brought up by hearing parents constitute the vast majority of DC population.

DC who were provided with an early access to sign language show the potential to become good readers and go on to achieve at least the same level as their hearing peers. American study ${ }^{21}$ has indicated that D/deaf adults with an early access to a sign language obtained similar reading comprehension results as hearing persons. It needs to be highlight that in this scientific project the level of reading comprehension in English was compared in four groups that included respectively: 1 . D/ deaf persons using sign language since their early years 2. D/deaf persons who have later access to language, whose parents were hearing and did not use sign language 3. bilingual hearing persons who had second language (English) classes at school 4. monolingual hearing persons (English speakers). The obtained results point to a series of similarities between D/deaf people who had early contact with a sign language and hearing bilinguals. In these both groups the subjects achieved higher levels of reading skills in English, similarly to monolingual persons. However, lower scores were found in D/deaf persons whose hearing parents did not know a sign language and who had delayed access to communication based on language.

All the above studies were undertaken by foreign scholars and concerned D/deaf persons from abroad. Despite the fact that this subject appears to be of crucial importance for D/deaf students and their

20 S. Goldin-Meadow, R.I. Mayberry, 2001, op. cit., pp. 222-229.

21 R.I. Mayberry, E. Lock, Age constraints on first versus second language acquisition: Evidence for linguistic plasticity and epigenesis. "Brain and Language", 2003, no. 87(3), pp. 369-384. 
educational success, so far in Poland the level of reading skills of D/deaf students, native signers of Polish Sign Language (PJM), has not been assessed. In order to fill this gap the conduction of this study has been undertaken, whose nature is innovative due to PJM perceived as facilitator of reading comprehension in D/deaf students.

\section{Main research}

The study compares the level of reading skills of two groups of children: DC, native signers of Polish Sign Language (polski język migowy, PJM) and HC. Also, it has been verified whether these children differ with regard to cognitive development. Cognitive characteristics have been selected that are crucial for the reading process ${ }^{22}$ : level of non-verbal intelligence (logical reasoning) and working memory.

\section{Research question and research hypothesis}

The study asked the following research question: Are the reading comprehension scores of $\mathrm{D} /$ deaf students, who are native signers, not different from the scores of hearing peers?

Considering the current studies concerning D/deaf persons using a sign language since early years ${ }^{23}$ we have made the hypothesis that D/deaf students, native signers of PJM, achieve the same level of reading comprehension as their hearing peers.

\section{Participants}

The study included the following groups: DC, native signers of PJM $(N=20)$, and HC $(N=20)$. Both groups of children were

22 P. De Jonge, P.F. De Jong, Working memory, intelligence and reading ability in children, "Personality and Individual Differences", 1996, no. 21(6), pp. 1007-1020.

${ }^{23}$ Ibidem, pp. 369-384. 
matched for sex (every group was as follows: boys $=4$, girls $=16$ ) and age.

D/deaf children. No child had co-existing disorders, disabilities or deficits other than hearing loss. All children attended special education schools for deaf and hard-of-hearing children. The age of DC was $6 ; 1$ to $12 ; 11(M=9 ; 11, S D=1 ; 11)$. The majority of children started their education at the age of $7(N=18)$ and only two children at the age of 6 . The inclusion criteria were having at least one D/deaf parent and using PJM as the first language. The majority of DC had both $\mathrm{D} /$ deaf parents $(N=18)$. All children since birth were surrounded by manual communication and were recognized as native signers of PJM. The children had a hearing loss of: severe degree $(N=7$, hearing loss of 75-90 dB) or profound degree $(N=18$, hearing loss over $90 \mathrm{~dB}$ ). As for aetiology of deafness in majority of cases it was genetic $(N=18)$, caused by an accident $(N=1)$ or unknown $(N=1)$. Hearing loss in all children occurred before 3 years of age (prelingual hearing loss).

Hearing children. No child had any disabilities or deficits reported by their parents/teachers. The age range of HC was $6 ; 6$ to $12 ; 7(M=9 ; 11, S D=1 ; 11)$. Two of the studied HC started their education at 6 whereas the majority $(N=18)$ started schooling at the age of 7. All children attended open access schools.

Both groups differed in social-economic status measured by the academic degree of their mothers $\left(\chi^{2}(1)=20,417, p<.001\right)$. The majority of DC's mothers had secondary education degrees $(N=19)$, whilst the majority of HC's mothers graduated from universities $(N=15)$.

Tasks

\section{“Reading” test (Grzywak-Kaczyńska)}

The "Reading" test written by M. Grzywak-Kaczyńska is designed to measure the level of reading comprehension. This is a quiet reading test which does not assess the techniques of reading. The test 
was originally designated for HC attending 1-3 grades of a primary school. Due to multiple literature sources ${ }^{24}$ indicating lower level of reading skills of DC than $\mathrm{HC}$ and to pilot surveys confirming this assumption it has been decided to use the "Reading" test to evaluate reading skills of DC attending 1-6 grades of a primary school. It consists of 3 practice items and 20 test items that were of similar testing structure. Each item contains one sentence or a short text and an attached drawing. Having read the sentence or the text a child is supposed to draw something on an attached picture or complete it appropriately. Every task includes a direct request to a child: "Draw/complete..." (e.g. Draw a leaf onto the apple or Draw a cross in the place where the bird sat after flying out of the cage). A child obtained 1 point for each correct answer. The maximum number of points for the "Reading" test was 20. At the beginning of the test a child was presented with an instruction containing clear explanations of all necessary activities. The instruction was presented to DC in PJM and to HC in Polish. While doing three practice items a researcher could assist and direct a child to a correct solution but they did not do it in test items. Completion of the "Reading" test took the children approximately 10-15 minutes depending on the pace of work. Drawing no. 1 exemplifies the task of the "Reading" test (Drawing no. 1).

Cat has just one whisker.

Draw him the second one

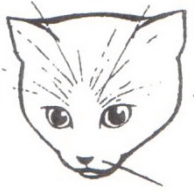

Drawing 1. The "Reading" test: task no. 5

The "Reading" test was adapted to the needs and abilities of DC. Modifications were introduced having consulted the specialists in the following fields: developmental psychology (M. Kielar-

24 J. Kotowicz, 2013, op. cit., pp. 173-184. 
-Turska), deaf education (J. Kotowicz and M. Schromova) and Polish studies as a foreign language (M. Stasiczek-Górna). Modifications to the test were introduced gradually and their results were verified in three pilot studies (first study: $N=4 \mathrm{DC}$, second pilot study: $N=20 \mathrm{DC}$, third pilot study: $N=20 \mathrm{HC}$ ). The introduced changes concerned, among the others, vocabulary (uncommon names such as: Mania, Jasia and Fela were changed for more modern ones: Magda, Asia and Justyna), syntax (pronouns were replaced with nouns, e.g. with her to the shore for with mother to the shore), cultural elements (DC might not be familiar with the game called blindman's bluff and thus, it was replaced by hide and seek) and drawings (not very clear drawing of a cat merging with a mouse was replaced with a more distinctive one).

\section{Working memory the Corsi Block test}

The test was presented on the computer, Milisecond Software. The Corsi Block test is a tool to measure non-verbal spatial working memory, in particular the ability to repeat a sequence in a reverse order. At the beginning of the test a child watched the instruction on a computer that had been recorded before. DC were shown the instruction in PJM while HC watched it in Polish. Corsi Blocks consisted of two parts. The first one tested the ability of repeating forward sequences. Nine scattered squares appeared on a computer screen and then the squares appeared one by one. A child's task was to remember this sequence and repeat the appearance of squares in that order. This part of the task was not analysed as it does not concern working memory but short-term memory. The second part of the task was very similar: having watched the squares appearing on the screen a child was asked to repeat their appearance but this time in reverse order (starting with the last up to the first one) This part allows for assessment of working memory, i.e. backward memory. At first the children were asked to memorize two elements, then the number of squares was increased. Each sequence length was pre- 
sented two times. In other words, the children had to remember two elements sequence two times, and then three elements sequence two times etc. The maximum number of squares appearing on the screen was nine. The children did not have to complete the whole test. If a child made a mistake in both attempts of a given sequence length the test was stopped. However, if even one sequence was remembered correctly the test was continued. With each sequence remembered correctly the child got one point for every element, e.g. if a child remembered 2 sequences of 2 elements, then 1 sequence of 3 elements and 1 sequence of 4 elements the child got the following number of points: $11(2+2+3+4=11)$.

\section{Raven's Progressive Matrices - Standard Version - Classic Form}

The Raven's Progressive Matrices - Standard Version - Classic Form (TMS-K) is a tool to measure general intelligence. The TMS-K Polish version is designated for children aged 5;11-15;11 and for adults over 16 years of age. The presented material is non-verbal: a child's task is to complete the pattern (matrix). The child is asked to select one fragment out of 6 (or 8) options that best matches the pattern. The TMS-K consists of 5 series (marked A, B, C, D and E, respectively) and each of them contains 12 tasks to solve. For every correct answer the child gets one point. Raw score is calculated for sten scores, appropriate for particular age groups. During the session the test was presented in a paper form. The instruction was presented in the child's first language (DC - PJM, HC - Polish).

\section{Procedure}

First the consents were obtained from the headmasters of schools where the studies were to be conducted. Then, a written consent was obtained from the parents of children who participated in the study. All the children provided their oral/sign consent to partici- 
pation in the project. All the study subjects were informed about the possibility to withdraw from the meeting at any time without giving a reason. After completing all tests the children received certificates of acknowledgement for participation in the study and a small gift, such as stationary supplies for school (e.g. pens, rubbers, etc.) If a child resigned from the study they also received the certificate and a small reward (one HC). The children performed tasks in a quiet room at school.

\section{Data analysis}

Statistical software: SPSS 24 (Statistical Package for the Social Sciences) was used to analyse the collected data. Univariate Analysis of Covariance (ANCOVA) comparing intergroup relation allowed for the analysis of intergroup differences (between DC and HC groups) at the level of a response variable, simultaneously controlling the effects of another variable (referred to as a covariate) on the response variable. ${ }^{25}$ For intergroup comparisons of the level of response variable also Student's t-test was used (with no covariate control).

\section{Results}

For the "Reading" test the children could obtain from 0 to 20 points. The average score in DC was 12 points $(\min =5, \max =20$, $M=12, S D=5)$. The average score in HC was 19 points $(\min =13$, $\max =20, M=19, S D=2)$. The results are presented in Chart no. 1 (Chart no. 1).

In the Raven's Progressive Matrices test the children could obtain results in sten scores of 1-10. The average DC's result in sten scores was $7(\min =5, \max =10, M=7, S D=1.7)$, and HC on average obtained 8 points $(\min =5, \max =10, M=8, S D=1.4)$.

${ }^{25}$ A. Field, Discovering statistics using SPSS, Sage, London 2013. 


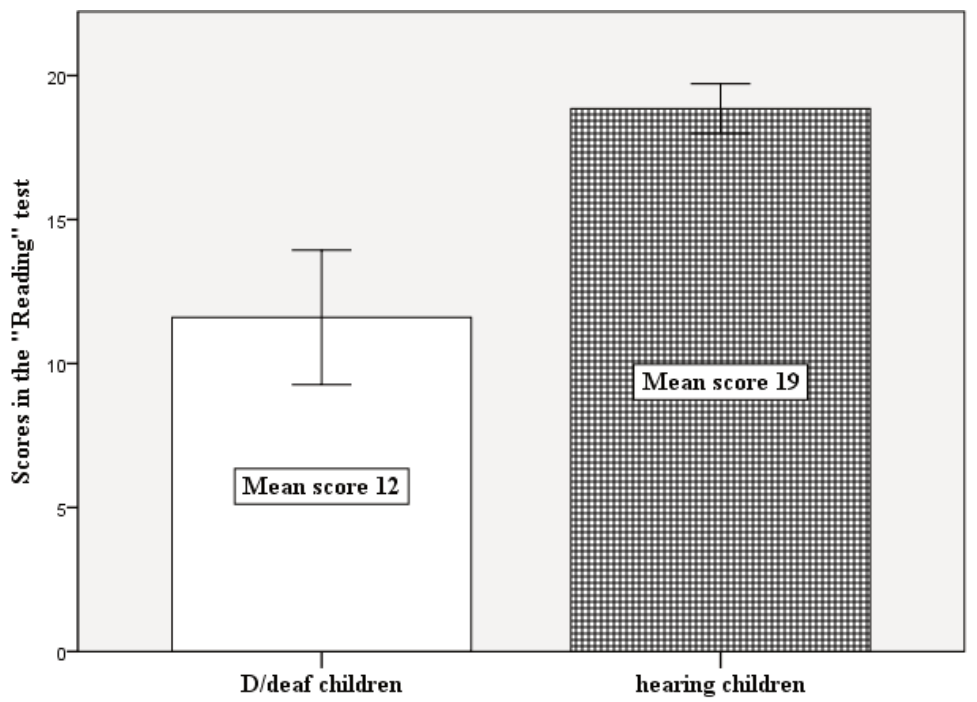

Chart 1. Mean scores in the "Reading" test for D/deaf children scores (left bar) and hearing children (right bar)

In the Corsi Block working memory test the children could obtain from 0 to 88 points. The average DC's score was $15(\min =0$, $\max =47, M=15, S D=15)$, and $\mathrm{HC}$ on average obtained 21 points $(\min =0, \max =54, M=21, S D=14)$.

Before the main analysis (comparisons of the level of reading comprehension scores between DC and HC) it was checked whether DC and HC study groups differ for intelligence and working memory. In order to evaluate these parameters two analyses were performed.

Firstly, using Student's t-test it was indicated that both groups do not differ in terms of non-verbal intelligence $(F(38)=-1.523$, $p=.136)$. For this analysis it was not necessary to include age as covariate because the obtained raw scores were calculated into sten scores for relevant age groups.

Secondly, in order to compare the level of non-verbal working memory univariate covariance analysis, ANCOVA, with age as covariant, was performed. ANCOVA indicated that the differences be- 
tween DC and HC for non-verbal working memory $(F(1.37)=2,150$, $p=.151, \eta 2=.055)$ are statistically insignificant. Age turned out to be a statistically significant covariate $(F(1.37)=11,432, p=.002, \eta 2=.236)$.

The main study analysis was verified for statistically significant intergroup differences between DC and HC in reading skills, simultaneously controlling age as a covariate. ANCOVA indicated that the difference of reading skills between DC and $\mathrm{HC}$ is statistically significant $(F(1.37)=56,427, p<.001, \eta 2=.604)$, and the age was a significant covariate $(F(1.37)=20,611, p<.001, \eta 2=.358)$. HC had significantly higher scores than their deaf peers.

\section{Limitations of the present studies}

The limitation of this study is the fact that both groups differed for socioeconomic status determined by the academic degree of the mother. HC's mothers had higher degrees than DC's mothers, which could be of significance for reading skills of the children.

\section{Conclusions}

The obtained data indicate that $\mathrm{D} /$ deaf students, native signers, have statistically significantly lower results in reading comprehension than their hearing peers. Both groups of children (DC and HC) did not differ in respect of intelligence nor capacity of non-verbal working memory. Both groups were matched for age and sex. Thus, the hypothesis of no differences in reading skills between HC and DC, whose first language of communication is PJM, has not been confirmed.

Therefore, a very important question arises: "How can the results obtained in the study be explained?" Of particular importance is the fact that deficits with regard to reading skills of D/deaf students appeared in DC group that since birth has had access to a sign language and did not have lower scores in the selected areas of cog- 
nitive development (level of intelligence and working memory) than the hearing peers.

Firstly, it should be noted that for DC, native signers of PJM, Polish written language is their second language. Therefore, D/deaf students' ability to read and write should be considered with regard to bilingualism, i.e. the first language being PJM and written Polish as the second one. Thus, it should be noted that this project compares the level of reading comprehension in Polish language that for $\mathrm{DC}$ was the second language and for $\mathrm{HC}$ was the first and dominant manner of communication. When learning to read in Polish HC refer to the spoken Polish language. Yet, DC for whom PJM is the first manner of communication cannot rely on this rich background of Polish language that monolingual HC have.

It should be also stressed that the specific nature of DC signedwritten bilingualism, significantly differs from HC bilingualism encompassing two spoken languages. In case of HC spoken bilingualism first they acquire speaking and listening competences in order to later learn to read and write. ${ }^{26}$ However, signed-written bilingual DC learn the second language mainly through writing, since the spoken language is not entirely available. Thus, it should be stressed that D/deaf students face a very demanding task when they almost simultaneously learn a foreign language (spoken) and its written form. ${ }^{27}$

Secondly, the obtained results may be treated as a factor suggesting that Polish educational system may not be properly prepared for the needs of DC using PJM. It appears that Polish deaf education may not ensure comprehensive development of DC's abilities and it appears that it does not provide optimal conditions for DC to achieve the same level of reading skills as their hearing peers. DC, who are native signers of PJM, begin to study in a school

${ }^{26}$ P. Tomaszewski, Mówić czy migać? Prawo dziecka głuchego do wychowania dwujęzycznego, [in:] D. Gorajewska (eds.), Społeczeństwo równych szans. Tendencje i kierunki zmian (pp. 113-124), Stowarzyszenie Przyjaciół Integracji, Warszawa 2005.

27 R.I. Hoffmeister, C.L. Caldwell-Harris, Acquiring English as a second language via print: The task for deaf children. "Cognition", 2014, no. 132(2), pp. 229-242. 
setting and they function normally in terms of language (sign language) and cognitive skills. Accordingly, they may be treated as D/deaf students who may become competent readers. The present studies appear to suggest that this potential is not fully used in Polish educational system. This may result from improper preparation of learning and teaching process for the needs and abilities of a D/deaf student for whom the first language is PJM. It seems to be associated with the lack of bilingual education that would develop both language competences, i.e. in a sign language and in writing. ${ }^{28}$

However, it should be stressed that more and more often the topic of special needs of D/deaf students using PJM is addressed. This is exemplified by related educational initiatives e.g. run by Magdalena Dunaj project entitled: "W stronę edukacji dwujęzycznej dzieci głuchych" (Towards bilingual education of deaf children). ${ }^{29}$ It seems also important to highlight that Pracownia Lingwistyki Migowej (Sign Language Linguistics Department) has prepared educational materials in PJM. ${ }^{30}$ Yet, there is still not sufficient methodology that would aid the development of reading skills of DC by referring to their competences in PJM. Thus, it seems crucial to become familiar with foreign ideas. e.g. computer-based trainings ${ }^{31}$ or learning programmes 32 , which could be inspiration for development of proper conditions to enhance reading skills of D/deaf students using PJM.

28 J. Kotowicz, Dwujęzyczność migowo-pisana dzieci głuchych. Komunikacja i procesy poznawcze. Wydawnictwo Uniwersytet Pedagogiczny im. KEN, Kraków 2018; M. Dunaj, W strone edukacji dwujęzycznej dzieci głuchych w Polsce. Co wiemy? Czego nie wiemy? Co należy robić?, Polski Związek Głuchych Oddział Łódzki, Łódź 2016.

${ }^{29}$ M. Dunaj, 2016, op. cit.

${ }^{30}$ P. Rutkowski, P. Mostowski. The use of Polish Sign Language (PJM) in bilingual textbooks for deaf students in Polish schools. "Language Learning Journal", 2020, no. 0(3), pp. 1-14.

${ }^{31}$ E. Holmer, M. Heimann, M. Rudner, Computerized sign language-based literacy training for deaf and hard-of-hearing children. Journal of Deaf Studies and Deaf, 2017, no. 22(4), pp. 404-421.

32 G. Tang, Sign Bilingualism in Deaf Education: From Deaf Schools to Regular School Settings, [in:] Bilingual and Multilingual Education, Encyclopedia of Language and Education, eds. O. García, A. Lin, S. May, Springer, Dordrecht 2016, pp. 191-203. 


\section{References}

Antia S.D., Jones P.B., Reed S., Kreimeyer K.H., Academic status and progress of deaf and hard-of-hearing students in general education classrooms, "Journal of Deaf Studies and Deaf Education", 2009, no. 14(3), pp. 293-311.

Chamberlain C., Mayberry R.I., American Sign Language syntactic and narrative comprehension in skilled and less skilled readers: Bilingual and bimodal evidence for the linguistic basis of reading. "Applied Psycholinguistics”, 2008, no. 29(3), pp. 367-388.

Czyż A., Plutecka K., Zarys audiofonologii edukacyjnej. Wydawnictwo Naukowe Uniwersytetu Pedagogicznego, Kraków 2018.

De Jonge P., De Jong P.F., Working memory, intelligence and reading ability in children, "Personality and Individual Differences", 1996, no. 21(6), pp. 1007-1020.

Dunaj M., W stronę edukacji dwujęzycznej dzieci głuchych w Polsce. Co wiemy? Czego nie wiemy? Co należy robić?, Polski Związek Głuchych Oddział Łódzki, Łódź 2016.

Field A., Discovering statistics using SPSS, Sage, London 2013.

Freel B.L., Clark M.D., Anderson M.L., Gilbert G.L., Musyoka M.M., Hauser P.C., Deaf Individuals' Bilingual Abilities: American Sign Language Proficiency, Reading Skills, and Family Characteristics. "Psychology", 2011, no. 02(01), pp. 18-23.

Goldin-Meadow S., Mayberry R.I., How Do Profoundly Deaf Children Learn to Read?, “Learning Disabilities Research and Practice", 2001, no. 16(4), pp. 222-229.

Hoffmeister R.J., Caldwell-Harris C.L., Acquiring English as a second language via print: The task for deaf children. “Cognition”, 2014, no. 132(2), pp. 229-242.

Holmer E., Heimann M., Rudner M., Computerized sign language-based literacy training for deaf and hard-of-hearing children. Journal of Deaf Studies and Deaf, 2017, no. 22(4), pp. 404-421.

Holmer E., Heimann M., Rudner M., Evidence of an association between sign language phonological awareness and word reading in deaf and hard-of-hearing children. "Research in Developmental Disabilities", 2016, no. 8, pp. 145-159.

Humphries T., Kushalnagar P., Mathur G., Napoli D.J., Padden C., Rathmann C., Ensuring language acquisition for deaf children: What linguists can do, "Language", 2014, no. 90(2), pp. 31-52.

Kotowicz J., Dwujęzyczność migowo-pisana dzieci głuchych. Komunikacja i procesy poznawcze. Wydawnictwo Uniwersytet Pedagogiczny im. KEN, Kraków 2018.

Kotowicz J., Nabywanie języka migowego - dyskusja stanowisk, "General and Professional Education”, 2015, no. 1, pp. 26-36.

Kotowicz J., Proces czytania głuchych, "Rocznik Komisji Nauk Pedagogicznych”, PAN Oddział Kraków, 2013, no. LXVI, pp. 173-184.

Mayberry R.I., del Giudice A.A., Lieberman A., Reading achievement in relation to phonological coding and awareness: a meta-analysis, "Journal of Deaf Studies and Deaf Education", 2011, no. 16(2), pp. 164-88. 
Mayberry R.I., Lock E., Age constraints on first versus second language acquisition: Evidence for linguistic plasticity and epigenesis. "Brain and Language", 2003, no. 87(3), pp. 369-384.

Mitchell R.E., Karchmer M.A., Chasing the Mythical Ten Percent: Parental Hearing Status of Deaf and Hard of Hearing Students in the United States, "Sign Language Studies", 2004, no. 4(2), pp. 138-163.

Novogrodsky R., Caldwell-Harris C., Fish S., Hoffmeister R.J., The Development of Antonym Knowledge in American Sign Language (ASL) and Its Relationship to Reading Comprehension in English. Language Learning, 2014, no. 64(4), pp. 749-770.

Qi S., Mitchell R.E., Large-scale academic achievement testing of deaf and hard-of-hearing students: Past, present, and future, "Journal of Deaf Studies and Deaf Education", 2012, 17(1), pp. 1-18.

Rutkowski P., Mostowski P., Polski język migowy narzędziem przeciwdziałania wykluczeniu, „Trendy. Internetowe Czasopismo Edukacyjne”, 2017, no. 1, pp. 18-22.

Rutkowski P., Mostowski P., The use of Polish Sign Language (PJM) in bilingual textbooks for deaf students in Polish schools. "Language Learning Journal", 2020, no. 0(3), pp. 1-14.

Strong M., Prinz P.M., A Study of the Relationship Between American Sign Language and English Literacy, "Journal of Deaf Studies and Deaf Education”, 1997, no. 2(1), pp. 37-46.

Tang G. Sign Bilingualism in Deaf Education: From Deaf Schools to Regular School Settings, [in:] Bilingual and Multilingual Education, Encyclopedia of Language and Education, eds. O. García, A. Lin, S. May, Springer, Dordrecht 2016, pp. 191-203.

Tomaszewski P., Mówić czy migać? Prawo dziecka głuchego do wychowania dwujęzycznego, [in:] D. Gorajewska (eds.), Społeczeństwo równych szans. Tendencje i kierunki zmian (pp. 113-124), Stowarzyszenie Przyjaciół Integracji, Warszawa 2005.

Traxler C.B., The Stanford Achievement Test, 9th Edition: National Norming and Performance Standards for Deaf and Hard-of-Hearing Students. "Journal of Deaf Studies and Deaf Education", 2000, no. 5(4), pp. 337-348.

no. number, $N$

mean, $M$

standard deviation, $S D$ 